\title{
Influence of process parameters on the color and texture of passion fruit albedo preserved in syrup
}

\author{
Influência de parâmetros do processo sobre a cor e textura de doces de albedo de maracujá em calda
}

\author{
Luisa Pereira FIGUEIREDO ${ }^{1 \star}$, Marali Vilela DIAS ${ }^{1}$, Wanderson Alexandre VALENTE ${ }^{1}$, Soraia Vilela BORGES ${ }^{1}$, \\ Anirene Galvão Tavares PEREIRA ${ }^{1}$, Patrícia Aparecida Pimenta PEREIRA ${ }^{1}$, Fabiana QUEIROZ ${ }^{1}$
}

\begin{abstract}
The industrialization of passion fruit in the form of juice produces considerable amounts of residue that could be used as food. The objective of the present study was to determine the effects of the volume of passion fruit juice added to the syrup and the cooking time on the color and texture of passion fruit albedo preserved in syrup. Multi-linear models were well fit to describe the value for $\mathrm{a}^{\star}$ (for the albedo) the values for $b^{*}$ (for the albedo and syrup), which exhibited high correlation coefficients of $98 \%, 84 \%$, and $88 \%$, respectively. The volume of passion fruit juice added and the cooking time of the albedos in the syrup, involved in the processing of passion fruit albedo preserves in syrup, significantly affected color analyses. The texture was not affected by the parameters studied. Therefore, the use of larger volumes of passion fruit juice and longer cooking time is recommended for the production of passion fruit albedo preserves in syrup to achieve the characteristic yellow color of the fruit.
\end{abstract}

Keywords: fruits; fruit preserves; quality.

\section{Resumo}

A industrialização do maracujá como suco gera uma considerável quantidade de resíduos que podem ser aproveitados como alimento. Este trabalho teve como objetivos determinar a influência do volume do suco de maracujá adicionado à calda e tempo de cozimento sobre a cor e a textura de doces de albedo de maracujá em calda. Modelos lineares foram bem ajustados para descrever o valor de ${ }^{\star}$ (para o albedo) e de b* (para o albedo e calda), apresentando altos coeficientes de correlação de $98 \%, 84 \%$ e $88 \%$, respectivamente. O volume de suco adicionado e o tempo de cozimento, envolvidos no processamento dos doces do albedo do maracujá em calda, influenciaram significativamente nas análises de cor. A textura não foi afetada pelos parâmetros estudados. Portanto, o uso de maiores volumes de suco de maracujá e maiores tempos de cozimento é recomendado para a produção de doces em calda do albedo do maracujá com coloração amarela característica da fruta. Palavras-chave: frutas; doces; qualidade.

\section{Introduction}

Brazil is one of the largest producers and consumers of passion fruit in the world with an estimated average production of 718.798 tons in 2009; the southeast and northeast regions account for more than $81 \%$ of national production (INSTITUTO..., 2009).

Yellow passion fruit (Passiflora edulis f. Flavicarpa) is the most commonly grown variety in Brazil, and it represents over $95 \%$ of orchards due to the quality of its fruit, vigor, productivity, and juice yield (MELETTI, 2011)

Yellow passion fruit has occupied a prominent place in fruit production, even when compared to other tropical fruits with higher consumption rates. Its share in the fresh produce market is ensured by fitting perfectly within this segment that places value on high value-added products (MELETTI, 2011). It is widely consumed due to its nutritional value and excellent organoleptic characteristics (MACHADO et al., 2003).

However, the use of passion fruit for juice production results in a large amount of residue since about 60 to $70 \%$ of the total weight of the fruit consists of the peel (albedo) and seeds (CÓRDOVA et al., 2005). Although consisting basically of carbohydrates and proteins, essential substances for human beings, the albedo is generally considered as a residue by industries, directly contributing to increase environmental pollution.

The processing of fruit residues is a promising alternative for residue use since it can provide an agreeable flavor, color, and texture to foods with an increase in sweetness allowing for product preservation for long periods and making its consumption possible in non-producing regions, thus increasing availability (GODOY et al., 2005; DAMIANI et al., 2009; MARTINS et al., 2010). Aiming to make use of the passion fruit peel, Oliveira et al. (2002) prepared preserves in syrup using passion fruit albedo aromatized with spices, and the results demonstrated the viability of reusing it in fruit preserves. Figueiredo et al. (2009) sensorially evaluated passion fruit albedo preserved in syrup and subjected to different process parameters and achieved generally high acceptance rates by 
the tasters. Other authors have also proposed the use of passion fruit peel for the production of preserves (NASCIMENTO et al., 2003; DIAS et al., 2011).

The quality of a food product is associated with the sensory parameters of color and texture. In the case of fruits or albedo in syrup, many factors affect these parameters, such as the cultivar, processing time and temperature, syrup concentration, acid concentration, fruit pre-treatment, and the types of sugar and acid used (SATO; SANJINEZ-ARGANDONA; CUNHA, 2006; BENLI; FENERCIOGLU, 2005; KATSIFERIS; ZOGZAS; KARATHANOS, 2008).

Nascimento et al. (2003) prepared passion fruit peel preserve varying the percentage of glucose syrup and type of acidulant. The authors obtained better results with the formulation that was acidified with passion fruit juice and sucrose. Sato, SanjinezArgandona and Cunha (2006) performed instrumental tests of color and texture to evaluate the effects of time and temperature on the processing of guava preserves in syrup. The tests that were subjected to higher temperatures underwent the greatest changes in color and texture.

Due to the fact that albedo is a rigid and insipid residue, the objectives of the present study were to evaluate the effects of the process parameters (volume of passion fruit juice added and cooking time of the albedos in the syrup) on the instrumental properties of color and texture.

\section{Materials and methods}

\subsection{Experimental design}

A complete factorial experimental design with 2 factors (volume of passion fruit juice added and cooking time of the albedos in the syrup), 2 levels, and three replications of the central point to evaluate the experimental error was used resulting in 7 treatments, as shown in Table 1.

\subsection{Characterization of the raw material}

Passion fruit (Passiflora edulis f. flavicarpa) in the mature stage (yellow intense peel with uniform distribution) and in healthy condition, harvested one day before processing, was provided by the Associação de Fruticultores de Lavras (Frutilavras) and stored under refrigeration after washing and

Table 1. Two level factorial design with three replications of the central point.

\begin{tabular}{ccccc}
\hline Treatments & $\mathrm{x}_{1}$ & $\mathrm{VJ}(\mathrm{mL})$ & $\mathrm{x}_{2}$ & CT (minutes) \\
\hline 1 & +1 & 90 & +1 & 20 \\
2 & -1 & 50 & +1 & 20 \\
3 & +1 & 90 & -1 & 10 \\
4 & -1 & 50 & -1 & 10 \\
5 & 0 & 70 & 0 & 15 \\
6 & 0 & 70 & 0 & 15 \\
7 & 0 & 70 & 0 & 15 \\
\hline
\end{tabular}

$\mathrm{x}_{1}=$ coded variable corresponding to $\mathrm{VJ} ; \mathrm{x}_{2}=$ coded variable corresponding to CT;

$\mathrm{VJ}=$ volume of juice; $\mathrm{CT}=$ cooking time. drying. In order to standardize the sample and reduce possible interference on the raw material, the fruits were standardized in terms of their diameter and length at $5.5 \pm 0.5 \mathrm{~cm}$ and $7.5 \pm 0.5 \mathrm{~cm}$, respectively, and total soluble solids of the juice at $11 \pm 0.5^{\circ}$ Brix.

\subsection{Processing of the albedo in syrup}

The passion fruit received was washed, sanitized in a $200 \mathrm{ppm}$ chlorine solution, cut manually, and pulped. The shells were cut vertically into 4 parts. They were then cooked for 5 minutes under pressure in a recipient containing sufficient potable water to cover them. The flavedo (outer yellow skin) was subsequently removed using a spoon.

The sugar/water syrup used to cook the albedos was prepared in a proportion of $1: 2(\mathrm{w} / \mathrm{v})$ and boiled for approximately 5 minutes in a stainless steel vat obtaining a soluble solids concentration of $40^{\circ}$ Brix, measured using an ATAGO model PR-100 digital refractometer (Atago Co, LTD, Japan). The passion fruit juice was extracted from the pulp of the fruit and added to the albedo in the syrup in a proportion of 1:2 (albedo/ syrup-passion fruit juice) (w/v), according to the experimental design shown in Table 1 using an open 5L stainless steel vat with manual stirring. The products were hot-filled into $250 \mathrm{~g}$ glass jars that were previously sterilized by immersion in boiling water for 15 minutes, closed with metal lids, animmediately cooled under running water, and stored at room temperature for 21 days, time previously determined to reach equilibrium in terms of syrup and albedo's pH and Brix (FIGUEIREDO et al., 2009).

\subsection{Instrumental color evaluation}

The color of the preserve samples was measured using a KONICA MINOLTA model CR-400 colorimeter (Minolta Corporation, Osaka, Japan), and the values were read directly on the three scales of the apparatus: scale "L", scale "a", scale "b": The readings were taken in triplicate for randomly chosen preserve samples of albedo and syrup, and the results were expressed as the mean values.

\subsection{Texture evaluation}

The passion fruit preserve compression force was measured using a TA.XT2 $i$ universal texturometer (Stable Micro Systems Ltd, Scarsdale, NY, USA) with an aluminum knife blade probe (model HDP/B5), speed of $5.0 \mathrm{~mm} / \mathrm{s}$, and compression of $20 \mathrm{~mm}$.

The design aimed to evaluate the effect of the independent variables or factors on the dependent variables or responses (physicochemical). The analysis of variance (ANOVA), determination of the regression coefficients, evaluation of the effects at the 5\% level of probability, and the production of response surfaces were all carried out using the STATISTICA software version 5.0 (STATSOFT, Tulsa, OK, USA). In the case of factors (parameters) showing significant effects on the responses, a multi-linear model was fit by multi-linear regression. 


\section{Results and discussion}

The following values and standard deviations were obtained for the parameters of $\mathrm{L}^{\star}$ (luminosity), $\mathrm{a}^{*}$ (intensity of green-red), $\mathrm{b}^{\star}$ (intensity of yellow-blue), and hardness $(\mathrm{N})$ for the fresh albedo: $44.43 \pm 1.48 ;-2.57 \pm 0.21 ; 1.30 \pm 0.18$ and $6.96 \pm 0.97$, respectively.

Table 2 shows the mean values and standard deviations obtained for $\mathrm{L}^{*}, \mathrm{a}^{*}$, and $\mathrm{b}^{*}$ for the albedo and syrup of the passion fruit albedo preserves in syrup. The $L^{\star}$ values obtained for the albedo were very similar among the treatments evaluated. This same behavior was observed for the $\mathrm{L}^{*}$ value in the syrup indicating that the different process parameters probably did not affect this response.

Therefore, an overall analysis of the results presented in Table 2 showed that processing associated with variations in the volume of passion fruit juice added and the cooking time of the albedos in the syrup changed the color of the processed samples when compared to that of the fresh fruit. Sato, SanjinezArgandona and Cunha (2006) working with industrialized samples of guava in syrup also reported changes in the color of the product when compared to the fresh fruit. The values obtained for the $\mathrm{a}^{*}$ parameter in the albedo in syrup were higher than those of the fresh albedo. The parameter L showed little variation of fresh albedo for albedo in syrup. The parameter $b^{*}$ showed the greatest variation since the yellow color was intensified during the processing of preserves, mainly because of the addition of passion fruit juice which has a characteristic yellow color.

In the case of passion fruit, which is predominantly yellow in color due to the large amount of carotenoids present (SOUSA et al., 2010), the $b^{*}$ value (blue to yellow) is much more representative of the color than the $a^{\star}$ value. Lower $b^{\star}$ values were found in the syrup of treatment 4 when compared to those of the other syrups, representing a less intense yellow color for that treatment, probably due to the smaller volume of passion fruit juice added to this treatment since passion fruit juice is rich in carotenoids. Although the same volume of passion fruit juice was added to treatment 2 , it exhibited higher $b^{\star}$ values (greater intensity of yellow color) showing the effect of cooking time on the final $b^{*}$ value.

From the results shown in Table 2 , the effects of the $\mathrm{x}_{1}$ and $\mathrm{x}_{2}$ variables, which refer to the volume of passion fruit juice added to the formulation and cooking time of the albedos in the syrup, on each response were evaluated and are shown in Table 3.

It can be seen that the volume of passion fruit juice added and the cooking time of the preserves were significant factors with respect to the parameters $a^{\star}$ and $b^{*}$ for the albedo and $b^{*}$ for the syrup.

In order to better visualize and discuss the effects of the factors, models were applied and surfaces produced for the responses where both factors were significant.

Equation 1 describes the $\mathrm{a}^{*}$ value as a function of the coded variables $\mathrm{x}_{1}$ and $\mathrm{x}_{2}$ for the albedo, and the correlation coefficient $\left(R^{2}\right)$ was 0.98 , showing that this model fit the experimental data well, allowing for the generation of response surfaces.

$\mathrm{a}^{*}=1.74-0.18 \mathrm{x}_{1}+0.63 \mathrm{x}_{2}-0.20 \mathrm{x}_{1} \mathrm{x}_{2}$

An analysis of Figure 1a shows that, as predicted by the model, higher $\mathrm{a}^{\star}$ values were obtained with smaller volumes of added juice and longer cooking times.

The processing of fruits in syrup shows some similarities with the osmotic dehydration process, which, according to Torreggiani and Bertolo (2001) and Ehabe, Eyabi Eyabi and Numfor (2006), results in mass transfer leading to a flow of water from the food to the solution due to the difference in

Table 2. Color parameters of the albedo and the syrup of the passion fruit albedo preserves in syrup.

\begin{tabular}{|c|c|c|c|c|c|c|}
\hline \multirow{2}{*}{ Treatments } & \multicolumn{3}{|c|}{ Albedo } & \multicolumn{3}{|c|}{ Syrup } \\
\hline & $\mathrm{L}^{*}$ & $a^{*}$ & $b^{*}$ & $\mathrm{~L}^{*}$ & $a^{*}$ & $b^{*}$ \\
\hline 1 & $43.32 \pm 4.04$ & $1.94 \pm 1.00$ & $22.51 \pm 1.66$ & $66.23 \pm 3.04$ & $-2.71 \pm 0.87$ & $40.80 \pm 2.48$ \\
\hline 2 & $38.61 \pm 1.63$ & $2.71 \pm 0.54$ & $18.17 \pm 1.28$ & $67.07 \pm 0.57$ & $-3.10 \pm 0.24$ & $35.72 \pm 1.19$ \\
\hline 3 & $40.74 \pm 2.08$ & $1.08 \pm 0.41$ & $10.86 \pm 1.36$ & $66.69 \pm 1.85$ & $-2.88 \pm 0.24$ & $27.85 \pm 2.14$ \\
\hline 4 & $44.99 \pm 3.41$ & $1.04 \pm 0.29$ & $8.09 \pm 1.69$ & $73.03 \pm 3.72$ & $-3.24 \pm 0.12$ & $16.68 \pm 2.34$ \\
\hline 5 & $39.91 \pm 1.28$ & $1.80 \pm 0.30$ & $10.58 \pm 1.51$ & $62.27 \pm 2.60$ & $-1.66 \pm 0.66$ & $36.02 \pm 0.78$ \\
\hline 6 & $40.21 \pm 2.59$ & $1.87 \pm 0.37$ & $11.08 \pm 3.23$ & $60.50 \pm 2.84$ & $-1.74 \pm 0.45$ & $34.98 \pm 2.10$ \\
\hline 7 & $41.20 \pm 1.19$ & $1.76 \pm 0.36$ & $11.86 \pm 2.27$ & $63.02 \pm 2.93$ & $-1.88 \pm 0.86$ & $34.78 \pm 2.22$ \\
\hline
\end{tabular}

Table 3. Evaluation of the effects of the factors on the color of the albedo and syrup.

\begin{tabular}{|c|c|c|c|c|c|c|}
\hline \multirow{2}{*}{ Factor } & \multicolumn{3}{|c|}{ Albedo } & \multicolumn{3}{|c|}{ Syrup } \\
\hline & $\mathrm{L}$ & $a^{*}$ & $b^{*}$ & $\mathrm{~L}$ & $a^{*}$ & $b^{*}$ \\
\hline Mean & 41.28 & 1.74 & 13.31 & 65.54 & -2.46 & 32.40 \\
\hline $\mathrm{x}_{1}$ & $0.23^{\mathrm{ns}}$ & $-0.36^{\star}$ & $3.55^{\star}$ & $-3.59^{\mathrm{ns}}$ & $0.375^{\mathrm{ns}}$ & $8.12^{*}$ \\
\hline $\mathrm{x}_{2}$ & $-1.90^{\mathrm{ns}}$ & $1.26^{*}$ & $10.86^{\star}$ & $-3.21^{\mathrm{ns}}$ & $0.155^{\mathrm{ns}}$ & $15.99^{\star}$ \\
\hline $\mathrm{x}_{1} \times \mathrm{x}_{2}$ & $4.48^{\star}$ & $-0.40^{*}$ & $0.78^{\mathrm{ns}}$ & $2.75^{\mathrm{ns}}$ & $0.015^{\mathrm{ns}}$ & $-3.04^{\star}$ \\
\hline
\end{tabular}

*Significant at the level of $5 \%$ probability; $\mathrm{ns}=$ not significant at the level of $5 \%$ probability; $\mathrm{x}_{1}=$ coded variable corresponding to VJ; $\mathrm{x}_{2}=$ coded variable corresponding to CT. 


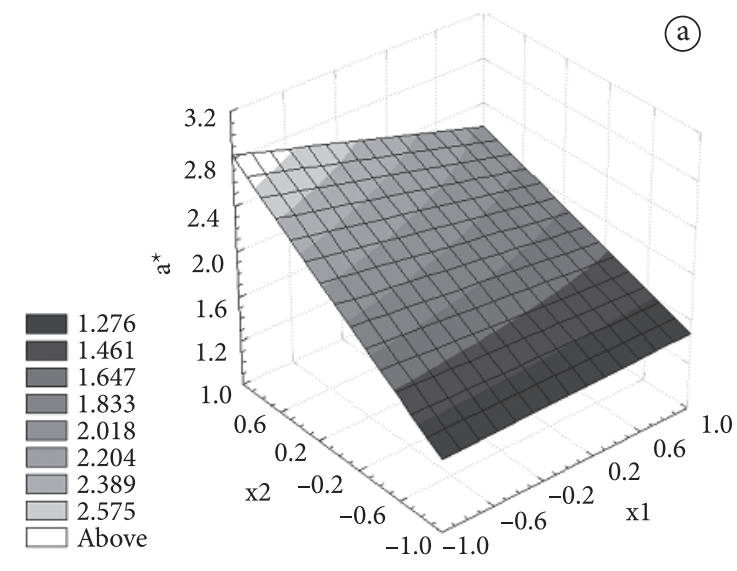

(a)
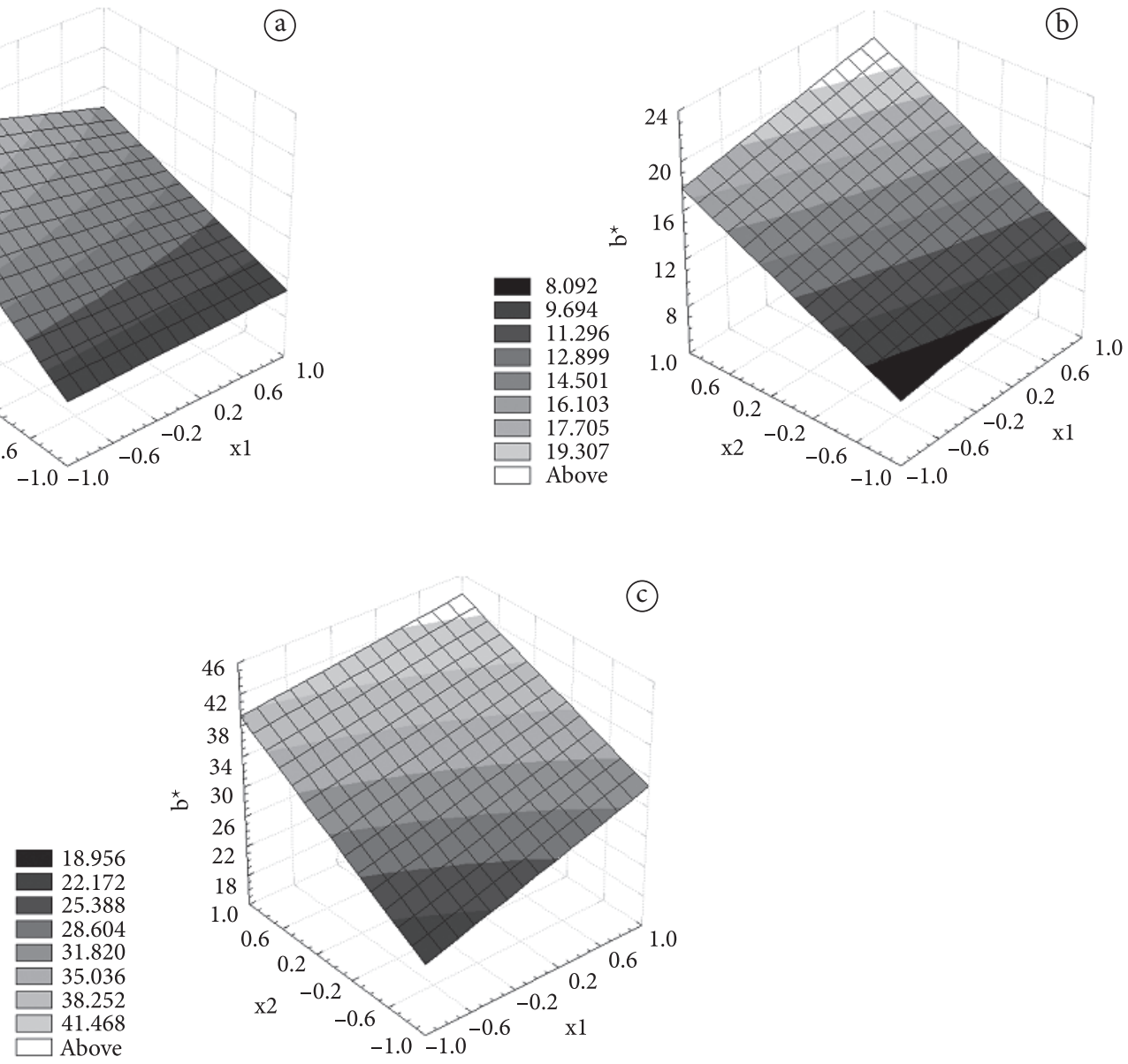

Figure 1. Variation in $\mathrm{a}^{\star}$ of the albedo as a function of the factors evaluated (a), variation in the $\mathrm{b}^{\star}$ value of the albedo as a function of the factors evaluated (b), variation in $b^{\star}$ value of the syrup as a function of the factors evaluated (c).

osmotic pressure, and a simultaneous transfer of solute from the solution to the food due to concentration gradients. However, it is important to emphasize that the process of obtaining fruit in syrup is more aggressive than osmotic dehydration process since it is carried out at high temperatures and high concentrations of sugar, thus causing further damage to the cellular structure of the fruit.

Raoult-Wack et al. (1991), working with osmotic dehydration, proposed a mathematical model for the simultaneous transport of water and solutes in agar-gel cubes, so as to explain the formation of a concentrated sucrose layer on the surface of the product.

Longer cooking times and the addition of smaller volumes of passion fruit juice resulted in highly viscous syrups due to the considerable evaporation of water and consequent concentration of the sugars. Thus, there could have been impregnation of sugars into the surface of the albedo caused by the transfer of solute from the solution to the fruit, and the higher $\mathrm{a}^{*}$ values of the albedo could therefore be associated with the presence of these sugars, due to caramelization during the cooking process, resulting in an increase in red color. Ponting et al. (1966) reported that the use of sucrose as a drying agent for pieces of fruit not only reduces the water content of the product but also protects its quality since the high concentration of sugar around the fruit prevents discoloration caused by oxidative enzymes.

Equations 2 and 3 describe the $b^{\star}$ value as a function of the coded variables $\mathrm{x}_{1}$ and $\mathrm{x}_{2}$ for the albedo and syrup, respectively. The correlation coefficients $\left(\mathrm{R}^{2}\right)$ were 0.84 and 0.88 , respectively, showing that the model fit the experimental data well, allowing for the generation of response surfaces (Figure $1 b, c$ ).

$\mathrm{b}^{*}=13.03+1.78 \mathrm{x}_{1}+5.43 \mathrm{x}_{2}$
$\mathrm{~b}^{*}=32.40+4.06 \mathrm{x}_{1}+8.00 \mathrm{x}_{2}-1.52 \mathrm{x}_{1} \mathrm{x}_{2}$

Figure $1 b, c$ show that the highest $b^{\star}$ values were obtained with larger volumes of added juice and longer cooking times for both the albedo and the syrup.

Beristain et al. (1990), investigating the osmotic dehydration of pineapple at atmospheric pressure, observed a predominance of water loss over solid gain during the osmotic dehydration process. According to the authors, this was due to the fact that it is difficult for sucrose to diffuse through the cell wall on account of its high molecular weight; the contrary occurred with the water molecules, whose diffusion was thus favored. Therefore, longer cooking times of the albedo possibly intensified the loss of water and increased surface impregnation of solids due to 
their difficulty passing through the albedo cell wall. This fact, associated with a greater addition of passion fruit juice, factor responsible for the increase in yellow color, resulted in higher $\mathrm{b}^{\star}$ values for the albedo.

At the same time, the addition of larger volumes of passion fruit juice to the syrup associated with longer cooking times of the albedos, i.e., the production of darker yellow and more concentrated syrups will probably result in higher $b^{\star}$ values for the syrups.

Table 4 shows the means and standard deviations of the hardness measurements.

Table 5 shows the evaluation of the effects of the factors on each response according to the above data.

The effects of the volume of passion fruit juice added to the formulation and cooking time of the albedos on the syrup were not significant for the hardness of the preserves (Table 5).

With regard to the fresh albedo, there was a general increase in the hardness of the albedos in syrup. From the texture analysis, it is observed that there was a change in the structure of the processed fruit since all treatments had mean hardness greater than that of the fresh albedo. Longer cooking times generally results in softer products, mainly due to degradation of the cell structure. Results similar to those of this study were reported by Sato, Sanjinez-Argandona and Cunha (2004), who investigated guavas in syrup. Other conditions, such as an acid $\mathrm{pH}$ value and an increase in soluble solids content (longer cooking times), could favor the natural gelation of the pectin present resulting in the formation of stronger gels (SHARMA; LIPTAY; LE-MAGUER, 1998). The processing conditions may have caused gelation of the pectin present in the albedo and/or entry of sugar into the fruit reinforcing structure. Grizotto, Aguirre and Menezes (2005) stated that besides the

Table 4. Hardness parameters of the albedo of the passion fruit albedo preserves in syrup.

\begin{tabular}{cc}
\hline Treatments & Hardness $(\mathrm{N})$ \\
\hline 1 & $24.20 \pm 3.42$ \\
2 & $30.14 \pm 2.53$ \\
3 & $18.95 \pm 2.68$ \\
4 & $25.72 \pm 1.95$ \\
5 & $17.66 \pm 3.31$ \\
6 & $24.92 \pm 3.57$ \\
7 & $31.11 \pm 3.89$ \\
\hline
\end{tabular}

Table 5. Evaluation of the effects of the factors on the hardness of the albedo.

\begin{tabular}{cc}
\hline Factor & Hardness \\
\hline Mean & 24.67 \\
$\mathrm{x}_{1}$ & $-6.35^{\mathrm{ns}}$ \\
$\mathrm{x}_{2}$ & $4.84^{\mathrm{ns}}$ \\
$\mathrm{x}_{1} \times \mathrm{x}_{2}$ & $0.42^{\mathrm{ns}}$
\end{tabular}

*Significant at the level of $5 \%$ probability; ns = not significant at the level of $5 \%$ probability; $\mathrm{x}_{1}=$ coded variable corresponding to $\mathrm{VJ} ; \mathrm{x}_{2}=$ coded variable corresponding to CT. sugar content, many other factors influence the properties of the gel, such as the addition of juice, $\mathrm{pH}$, and type of pulp used. According to Stolle-Smiths et al. (2000), the mechanical properties of cellular foods depend to a large extent on their composition and on the way they are processed, and, therefore, the degree of maturity of the fruit and the processing parameters are factors which strongly affect these properties.

Considering that the maturation of the fruits was standardized and all process parameters were controlled, it is believed that the discrepancy among the standard deviations of the data for hardness of albedos preserved in syrup are due to the processes involved in the production of preserves. Texture analysis was performed 21 days after the production of preserves. Figueiredo et al. (2009) reported that this period of time is enough to reach an equilibrium $\mathrm{pH}$ and Brix of the syrup and albedo; however, in this study the hardness profile of albedos was not evaluated. Therefore, it is believed that at the time of analysis, the albedos in syrup might not yet have reached their osmotic and cellular balance, which could result in oscillations in the texture values. Given these results, further studies on the behavior of the shelf life texture of these preserves should be carried out for a better understanding of this property.

\section{Conclusions}

The variables under study significantly affected the color analyses and did not affect the texture analyses. Therefore, the use of larger volumes of passion fruit juice and longer cooking time for the production of passion fruit albedo preserved in syrup to achieve the characteristic yellow color of the fruit is recommended.

\section{Acknowledgements}

The authors are grateful to FAPEMIG for the financial support and to FRUTILAVRAS for their partnership in this study.

\section{References}

BENLI, H.; FENERCIOGLU, H. Effects of filling liquids and storage conditions on canned pomegranates. Gida, v. 30, n. 1, p. 49-54, 2005.

BERISTAIN, C. I. et al. Mass transfer during osmotic dehydration of pineapple rings. Food Science and Technology International, v. 25, n. 5, p. 576-582, 1990.

CÓRDOVA, K. R. V. et al. Características físico-químicas da casca do maracujá amarelo (Passiflora edulis Flavicarpa Degener) obtida por secagem. Boletim do Centro de Pesquisa e Processamento de Alimentos, v. 23, n. 2, p. 221-230, 2005.

DAMIANI, C. et al. Avaliação química de geléias de manga formuladas com diferentes níveis de cascas em substituição à polpa. Ciência e Agrotecnologia, v. 33, n. 1, p. 177-184, 2009. http://dx.doi. org/10.1590/S1413-70542009000100025

DIAS, M. V. et al. Estudo de variáveis de processamento para produção de doce em massa da casca do maracujá (Passiflora edulis f. flavicarpa). Ciência e Tecnologia de Alimentos, Campinas, v. 31, n. 1, p. 65-71, 2011. http://dx.doi.org/10.1590/S010120612011000100008 
EHABE, E. E.; EYABI EYABI, G. D.; NUMFOR, F. A. Effect of sugar and $\mathrm{NaCl}$ soaking treatments on the quality of sweet banana figs. Journal of Food Engineering, v. 76, p. 573-578, 2006. http://dx.doi. org/10.1016/j.jfoodeng.2005.06.006

FIGUEIREDO, L. P. et al. Efeito da adição de suco de maracujá e tempo de cozimento sobre a qualidade de doces do albedo de maracujá em calda. Ciência e Tecnologia de Alimentos, v. 29 , n. 4 , p. $840-846,2009$. http://dx.doi.org/10.1590/S010120612009000400022

GODOY, R. C. B. et al. Estudo de compotas e doces cristalizados elaborados com diferentes albedos cítricos. Boletim do Centro de Pesquisa de Processamento de Alimentos, v. 23, n. 1, p. 95-108, 2005.

GRIZOTTO, R. K.; AGUIRRE, J. M.; MENEZES, H. C. Frutas estruturadas de umidade intermediária obtidas de polpas concentradas de abacaxi, manga e mamão. Ciência e Tecnologia de Alimentos, v. 25, n. 4, p. 691-697, 2005. http://dx.doi.org/10.1590/ S0101-20612005000400011

INSTITUTO BRASILEIRO DE GEOGRAFIA E ESTATÍSTICA - IBGE. Maracujá: área plantada e quantidade produzida. Brasília, 2009. (Produção Agrícola Municipal, 2009). Disponível em: <http://www. sidra.ibge.gov.br>. Acesso em: 06 ago. 2012.

KATSIFERIS, T.; ZOGZAS, N.; KARATHANOS, T. Mechanical properties and structure of unripe oranges during processing of "spoon sweets". Journal of Food Engineering, v. 89, p. 149-155, 2008. http://dx.doi.org/10.1016/j.jfoodeng.2008.04.014

MACHADO, S. S. et al. Caracterização física e físico-química de frutos de maracujá amarelo provenientes da região de Jaguaquara - Bahia. Magistra, v. 15, n. 2, p. 223-229, 2003.

MARTINS, M. L. A. et al. Alterações físico-químicas e microbiológicas durante o armazenamento de doces de umbu (Spondias tuberosa Arr. Camara) verde e maduro. Ciência e Tecnologia de Alimentos, v. 30, p. 60-67, 2010. http://dx.doi.org/10.1590/S010120612010005000004

MELETTI, L. M. M. Avanços na cultura do maracujá no Brasil. Revista Brasileira de Fruticultura, volume especial, p. 83-91, 2011.

NASCIMENTO, R. M. F. et al. Características sensoriales, microbiológicas y físico-químicas de dulces em masa de cáscara de maracujá amarilllo. Alimentaria, v. 347, p. 97-100, 2003.
OLIVEIRA, L. F. et al. Aproveitamento alternativo da casca do maracujá-amarelo (Passiflora edulis f. Flavicarpa) para produção de doce em calda. Ciência e Tecnologia de Alimentos, v. 22 , n. 3, p. 259-262, 2002. http://dx.doi.org/10.1590/S010120612002000300011

PONTING, J. D. et al. Osmotic Dehydration of Fruits. Food Tecnology, v. 10, p. 125-128, 1966.

RAOULT-WACK, A. L. et al. Simultaneous water and solute transport in shrinking media - Part 2: A compartmental model for dewatering and impregnation soaking processes. Drying Technology, v. 9, n. 3, p. 613-630, 1991. http://dx.doi.org/10.1080/07373939108916699

SATO, A. C. K.; SANJINEZ-ARGANDONA, E. J.; CUNHA, R. L. Avaliação das propriedades físicas, químicas e sensorial de preferência de goiabas em calda industrializadas. Ciência e Tecnologia Alimentos, v. 24, n. 4, p. 550-555, 2004. http://dx.doi. org/10.1590/S0101-20612004000400012

SATO, A. C. K.; SANJINEZ-ARGANDONA, E. J.; CUNHA, R. L. The effect of addition of calcium and processing temperature on the quality of guava in syrup. International Journal of Food Science and Technology, v. 41, p. 417-424, 2006. http://dx.doi. org/10.1111/j.1365-2621.2005.01088.x

SHARMA, S. K.; LIPTAY, A.; LE-MAGUER, M. Molecular characterization, physico-chemical and functional properties of tomato fruit pectin. Food Research International, v. 30, n. 7, p. 543-547, 1998. http://dx.doi.org/10.1016/S0963-9969(98)00017-9

SOUSA, P. H. M. et al. Storage stability of a tropical fruit (cashew apple, acerola, papaya, guava and passion fruit) mixed nectar added caffeine. International Journal of Food Science and Technology, v. 45 , p. $2162-2166,2010$. http://dx.doi.org/10.1111/j.13652621.2010.02383.x

STOLLE-SMITHS, T. et al. Preheating effects on the textural strengh of canned green beans. 1. Cell wall chemistry. Journal of Agricultural and Food Chemistry, v. 48, n. 11, p. 5.269-5.277, 2000.

TORREGGIANI, D.; BERTOLO, G. Osmotic treatments in fruit processing: chemical, physical and structural effects. Journal of Food Engineering, v. 49, n. 2, p. 247- 256, 2001. http://dx.doi. org/10.1016/S0260-8774(00)00210-7 